\title{
Influencias de tipos iconográficos paganos en obras plásticas andaluzas de la Edad Moderna
}

\author{
Jesús Porres Benavides ${ }^{1}$
}

Recibido: 7 de abril de 2020 / Aceptado: 6 de junio de 2020 / Publicado: 3 de julio de 2020

Resumen. En este artículo se analiza la posible influencia de la escultura clásica en la escultura religiosa en obras plásticas del arte andaluz y algunas obras concretas especialmente del periodo barroco. También se analiza el coleccionismo de esculturas clásicas en la España Moderna y la posible influencia de estas en la escultura del momento. Se estudian algunas iconografías en concreto como el Eros dormido y su posible transliteración en el tema del niño Jesús dormido, así como la posible influencia del Sileno con Dionisos niño en algunas creaciones de San José o la del Apolo Sauróctono en San Sebastián. Asimismo, se estudia la creación de algunos escultores del barroco andaluz como Alonso Cano y Juan de Mesa y la posible utilización de fuentes clásicas por ambos.

Palabras clave: escultura clásica; pintura; iconografía; coleccionismo; Artes Plásticas en Andalucía.

\section{[en] Influences of pagan iconographic types on Andalusian plastic works of the early Modern Age}

\begin{abstract}
In this article the possible influence of classical sculpture on religious sculpture in plastic works of Andalusian art is analyzed and some works especially from the Baroque period. Also the collecting of classical sculptures in early modern Spain and the possible influence of these on the sculpture of the moment is analyzed. Some specific iconographies are studied, such as the sleeping Eros and it's possible transliteration on the theme of the sleeping baby Jesus, as well as the possible influence of Silenus with the child Dionysus on some creations of San José or the Apollo Sauroctonous in San Sebastián. Likewise, the creation of some Andalusian baroque sculptors such as Alonso Cano and Juan de Mesa and the possible use of classic fonts by both is studied.
\end{abstract}

Keywords: Classical Sculpture; Painting; Iconography; Collecting; Plastic Arts in Andalusia.

Sumario. 1. Introducción. 2. El coleccionismo de esculturas clásicas en la España Moderna. 3. La influencia de las esculturas clásicas durante la época Moderna en España. 4. La influencia de modelos clásicos en la representación de algunas iconografías cristianas. 5. Conclusiones. 6. Fuentes y referencias bibliográficas.

Cómo citar: Porres Benavides, Jesús. "Influencias de tipos iconográficos paganos en obras plásticas andaluzas de la Edad Moderna”. Eikón Imago 15 (2020): 527-550.

1 Universidad Rey Juan Carlos (Madrid).

Correo electrónico: jesus.porres@urjc.es

ORCID: https://orcid.org/0000-0002-4042-7426 


\section{Introducción}

A principios del siglo XX el historiador del arte alemán Aby Warburg plasmó en su magistral obra Atlas Mnemosyne la concatenación de obras artísticas y las influencias que éstas tienen sobre las siguientes, a manera de grandes árboles genealógicos. Se trataba en aquel entonces de un planteamiento novedoso que permitía observar la evolución iconográfica. Dicha obra influyó en Erwin Panofsky y en posteriores tratados de iconografía e iconología que venían a demostrar "que grandes personajes o símbolos concretos -tras pasar por el filtro de influencias de los períodos históricos-, sufrían reutilizaciones y reinterpretaciones"2. Este fenómeno también afecta a la iconografía cristiana, que en muchos casos bebe directamente de las formas de representación plástica de los mitos clásicos.

En los primeros siglos del Cristianismo (del I al IV), miembros de la naciente Iglesia estaban en contra de las representaciones de imágenes porque temían caer en el paganismo ${ }^{3}$ y consideraban que era mejor no copiar a la creación realizada por el único "hacedor". Probablemente aún estaba vivo el precepto judío del Antiguo Testamento de no adorar imágenes hechas por el hombre:

No te harás imagen, ni ninguna semejanza de lo que esté arriba en el cielo, ni abajo en la tierra, ni en las aguas debajo de la tierra. No te inclinarás a ellas, ni las honrarás; porque yo soy tu Dios (Ex 20,4-6).

A toda esta serie de precauciones que podemos considerar normales en el contexto cultural de aquel momento, debemos sumar otras de carácter técnicoeconómico y es que las primeras comunidades cristianas no disponían de muchos medios para la realización de obras artísticas de calidad, a no ser que hubiera algún artesano en su comunidad. Todo ello contribuye a que las primeras representaciones sean de carácter simbólico, haciendo alusión por ejemplo a la Eucaristía o a Cristo y con unas composiciones sencillas pero eficaces. Durante el periodo paleocristiano ya se observa la influencia del clasicismo en el arte religioso, por ejemplo, en el tipo iconográfico del Buen Pastor, y este legado clásico se mantiene a lo largo de toda la Edad Media.

Para que se produjera una conexión entre el cristianismo y la mitología clásica resultó fundamental la labor de los monasterios medievales en su recuperación de las obras y la tradición clásica, contribuyendo a la tardía aparición de muchas representaciones plásticas en la religión cristiana.

Posteriormente en el Renacimiento un erudito como el cardenal Gabriele Paleotti trata en su Discorso intorno alle immagine sacre e profane una serie de medidas favorables a la iconografía devota y en contra de la indecorosa, ya sea sacra o profana. Según él, los retratos de los dioses de la antigüedad grecolatina conllevaban abusos y riesgos inopinados, pues está "próxima al paganismo y también es propensa a la perpetuación del paganismo, so excusa de estudio de las

Erwin Panofsky, Estudios sobre iconología (1972. Reimpresión, Madrid: Alianza, 2002), 94.

Pensando también la cantidad de mártires que habían ofrecido su vida al negarse a hacer ofrendas a las

“imágenes” de dioses paganos. 
artes y las letras clásicas, el adorno de hogares y la exhibición de alegorías morales" 4 .

\section{El coleccionismo de esculturas clásicas en la España Moderna}

El coleccionismo de esculturas clásicas se revitalizará precisamente a partir del Renacimiento italiano. Dicho coleccionismo será muy relevante desde el siglo XV en los diferentes estados italianos, con especial énfasis en los Estados Pontificios, debido fundamentalmente a que se trataba de la principal cantera de obras clásicas que, conforme se iban descubriendo, pasaban a engrosar las diferentes colecciones papales y de otros personajes de la alta sociedad ${ }^{5}$.

Poseer y exhibir obras artísticas formaba parte del código de la buena sociedad de la época, cuyas colecciones ganaban en prestigio y erudición gracias a la presencia de antigüedades. Todo ello contribuyó a que, junto al mecenazgo del Vaticano, las grandes familias italianas patrocinaran las empresas arqueológicas del momento ${ }^{6}$.

Uno de los espacios que contendrá dichas colecciones de escultura clásica será el patio del Belvedere. Dicho patio fue un encargo de Julio II, Giuliano della Rovere, cuando encomendó a Bramante en 1503 el "reto de urbanizar el espacio existente entre los palacios Vaticanos y la villa del Belvedere"7. Desafortunadamente, Julio II murió en 1513 y Bramante poco después, con lo que las obras no se reanudaron hasta que Pirro Ligorio en 1565 se hizo cargo de ellas.

El interés coleccionista que hubo en España durante el siglo XVI no es comparable con el que se produjo en Italia ni con las colecciones que empezaron a formarse en otros países, como la creada por Francisco I en Francia. Algunos han achacado este menor interés no sólo a una menor disponibilidad de piezas sino también a razones ideológicas y artísticas que "decantaban el gusto hacia la pintura o los temas religiosos" ${ }^{\text {. }}$. No obstante, podríamos citar algunos ejemplos relevantes como las colecciones de ciertos aristócratas o altos funcionarios entre las que destacan don Diego Hurtado de Mendoza, don Luis de Ávila y el duque de Alcalá. A este restringido grupo habría que sumar las colecciones reales de Felipe II, "pese al escaso interés de éste por la escultura antigua clásica y además pagana” " ${ }^{9}$ la del príncipe Carlos y la de María de Hungría, tía del rey, así como las del virrey de

4 Carlos Alberto González Sánchez, El espíritu de la imagen (Madrid: Ediciones Cátedra, 2017), 55.

5 Sobre esto se puede leer a Francis Haskell y Nicholas Penny, El Gusto y el arte de la antigüedad: el atractivo de la escultura clásica: 1500-1900, trad. José Antonio Suárez Hernández (Madrid: Alianza, 1990). También en el ámbito hispánico se puede consultar José Miguel Morán Turina y Fernando Checa Cremades, El coleccionismo en España: de la cámara de maravillas a la galería de pinturas (Madrid: Ediciones Cátedra, 1985).

6 Fabiola Salcedo Garcés, “Las colecciones de escultura clásica en la Roma de Velázquez”, en Velázquez: esculturas para el Alcázar (Madrid: Real Academia de Bellas Artes de San Fernando, 2007), 53.

7 Salcedo, "Las colecciones de escultura clásica”, 53.

8 José Beltrán Fortes, "La escultura clásica en el coleccionismo erudito de Andalucía (siglos XVII-XVIII)”, en El coleccionismo de escultura clásica en España: actas del simposio (Madrid: Museo Nacional del Prado, 2001), 143-172.

9 David Gimilio Sanz, "Poder, humanismo y religiosidad en tiempos del patriarca Juan de Ribera en Valencia: su colección de escultura clásica”, Espacio, Tiempo y Forma, Serie VII, Historia del Arte, $2^{\mathrm{a}}$ época, no 2, (2014): 22. 
Nápoles don Pedro de Toledo y los duques de Luna y de Villahermosa ${ }^{10}$ que se han estudiado en las últimas décadas.

El ambiente cultural de Sevilla propició una cierta afición por el coleccionismo. Así, podríamos citar la colección de Argote de Molina, o la de escultura clásica en el palacio del duque de Alcalá conocido como "la casa de Pilatos", actualmente perteneciente al ducado de Medinaceli ${ }^{11}$. La entrada en la ciudad de oro y otros productos importados de América contribuyeron a trasladar una gran opulencia a los palacios y residencias señoriales, en los que se llevaron a cabo suntuosas reformas, casi todas realizadas en un estilo renacentista con marcado acento italiano, del que la mencionada casa de Pilatos fue pionera. Recordemos que don Fadrique, marqués de Tarifa y Alcalá, en una de las escalas de su peregrinación a Tierra Santa, encargará a los talleres de los Aprile en Génova la portada clásica a modo de arco de triunfo, así como veinticuatro columnas de mármol y dos fuentes de taza ochavada ${ }^{12}$.

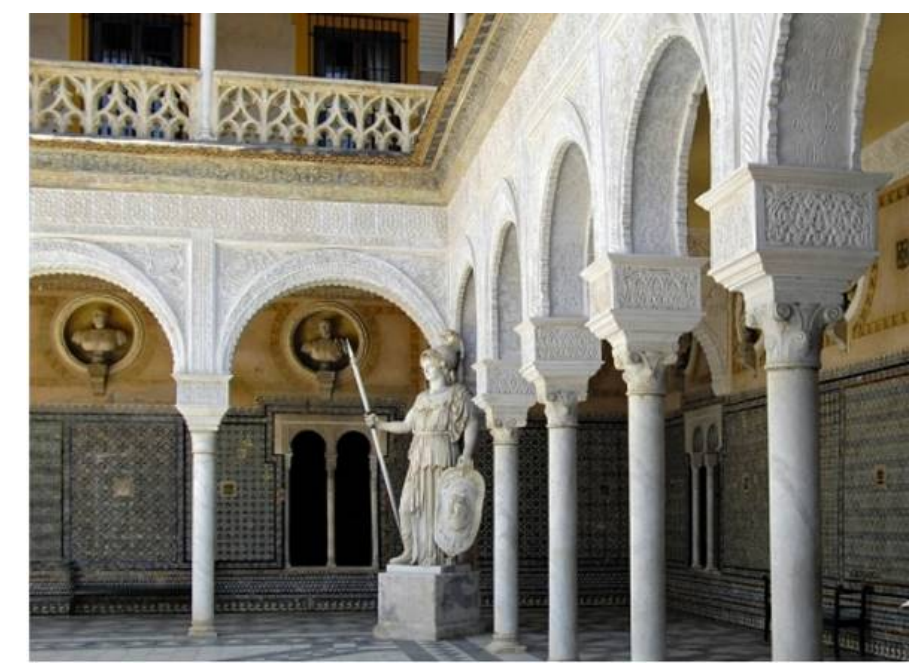

Figura 1. Patio de la "casa de Pilatos", siglo XVI, Sevilla. Fuente: Conoce mi ciudad https://conocemiciudad.com/tag/que-ver-en-sevilla/page/4/

Su sobrino Per Afán de Ribera, I duque de Alcalá, título otorgado por el rey Felipe II en 1558, fue famoso por la extraordinaria colección de esculturas de la Antigüedad que reunió durante su estancia en Nápoles como virrey y que finalmente mandó al palacio sevillano (fig. 1). En su mayoría fueron reunidas en Nápoles entre 1558 y 1571, fruto de un entorno humanista y erudito, de obligada referencia para la arqueología, la historia del arte y la literatura del coleccionismo, como ejemplo de supervivencia de una colección privada, que contrasta con lo ocurrido en la mayoría de colecciones contemporáneas a ésta, que bien se han

10 Cf. Ibid.,17.

11 Jesús Porres Benavides, Juan Bautista Vázquez El Viejo, un artista castellano en Sevilla (Sevilla: Editorial Universidad de Sevilla, 2019), 26.

12 Sobre el ambiente humanístico en la Sevilla del momento se puede consultar Vicente Lleó Cañal, Nueva Roma: mitología y humanismo en el renacimiento sevillano (1979. Reimpresión, Sevilla, CEEH, 2012). 
perdido o sólo han quedado como meras descripciones para la posteridad en los libros de viaje.

El entonces secretario de la embajada española en Roma, Juan Verzosa, cita al duque como coleccionista al mismo nivel que Cosme de Médicis o el cardenal Farnese $^{13}$. No en balde, recuerda Markus Trunk, varios anticuarios italianos tenían la orden de comprar para él esculturas antiguas procedentes de la zona de la Campania y el Lazio. Además, el papa Pio V le hizo algún regalo de esculturas procedentes del Vaticano ${ }^{14}$, que fueron a adornar tanto la "casa de Pilatos" como el castillo de Bornos, en el cual el arquitecto italiano Benvenuto Tortello había construido una galería para acoger dichas esculturas.

Igualmente en Sevilla ya en el siglo XVII destacan las colecciones del humanista Rodrigo Caro, conocida por referencias y que donó a su muerte al duque de $\operatorname{Arcos}^{15}$ o la que poseía Juan de Córdoba en Lora de Estepa (Sevilla), que con el paso del tiempo acabaría integrándose en la de Francisco de Bruna ${ }^{16}$, un personaje ilustrado de fines del XVIII ${ }^{17}$. También en el XVIII tendríamos la colección de Guillermo Tyrry en Cádiz, o la de Pedro Leonardo de Villacevallos en Córdoba.

Fuera de Andalucía destacaron personajes como Juan de Ribera (1532-1611), arzobispo de Valencia, influido por su formación humanista y por su relación con su padre Per Afán de Ribera, duque de Alcalá y virrey de Nápoles ${ }^{18}$. Juan de Ribera gastó dos mil ducados en una serie de esculturas antiguas y piezas arquitectónicas. En esta colección, de la que desgraciadamente sólo nos han llegado algunas obras conservadas en el Real Colegio Seminario del Corpus Christi, está por ejemplo la denominada La palletera -vendedora de pajuela-, figura femenina togada encontrada y traída desde Pozzuoli (Nápoles). Más interesante para esta investigación, es la serie de bustos de emperadores romanos, transformados luego en imágenes de mártires cristianos mediante detalles dorados y policromos como rajas en los cuellos u otras señales de martirio que constituyen un claro exponente de los "travestismos" iconográficos que se suelen dar en arte (fig. 2). También el conde de Benavente en 1612 instalará en el jardín de su palacio "un importante conjunto de estatuas, en su mayor parte mármoles, alabastros, jaspes y bronces de origen clásico” ${ }^{19}$.

13 Markus Trunk, "La colección de esculturas antiguas del primer duque de Alcalá de la Casa de Pilatos en Sevilla”, en El coleccionismo de escultura clásica en España: actas del simposio: 21 y 22 de mayo de 2001 (Madrid: Museo Nacional del Prado, 2001), 91.

14 Cf. Ibid., 91.

15 Beltrán Fortes, "La escultura clásica en el coleccionismo erudito...”, 148.

16 José Ramón López Rodríguez, "Don Francisco de Bruna y la colección de estatuas de Juan de Córdoba Centurión”, en Francisco de Bruna (1719-1807) y su colección de antigüedades en el Real Alcázar de Sevilla (Sevilla: Editorial Universidad de Sevilla, 2018), 137-164.

17 Es muy llamativo como el 15 de octubre de 1788, escribía Bruna al marqués de Floridablanca "para que el rey ordenara al prior del monasterio de la Cartuja de Santiponce que le entregue - unas esculturas aparecidas en Itálica, entre ellas una de un Hermes Dionysophoros y le dice "están desnudas sin más que la pretexta a la espalda (...) la una que está boca arriba es idéntica al Apolo del Belvedere” Ibid., 164.

18 Gimilio Sanz, "Poder, humanismo y religiosidad...”, 13.

19 Morán Turina y Checa Cremades, El coleccionismo en España..., 147. 


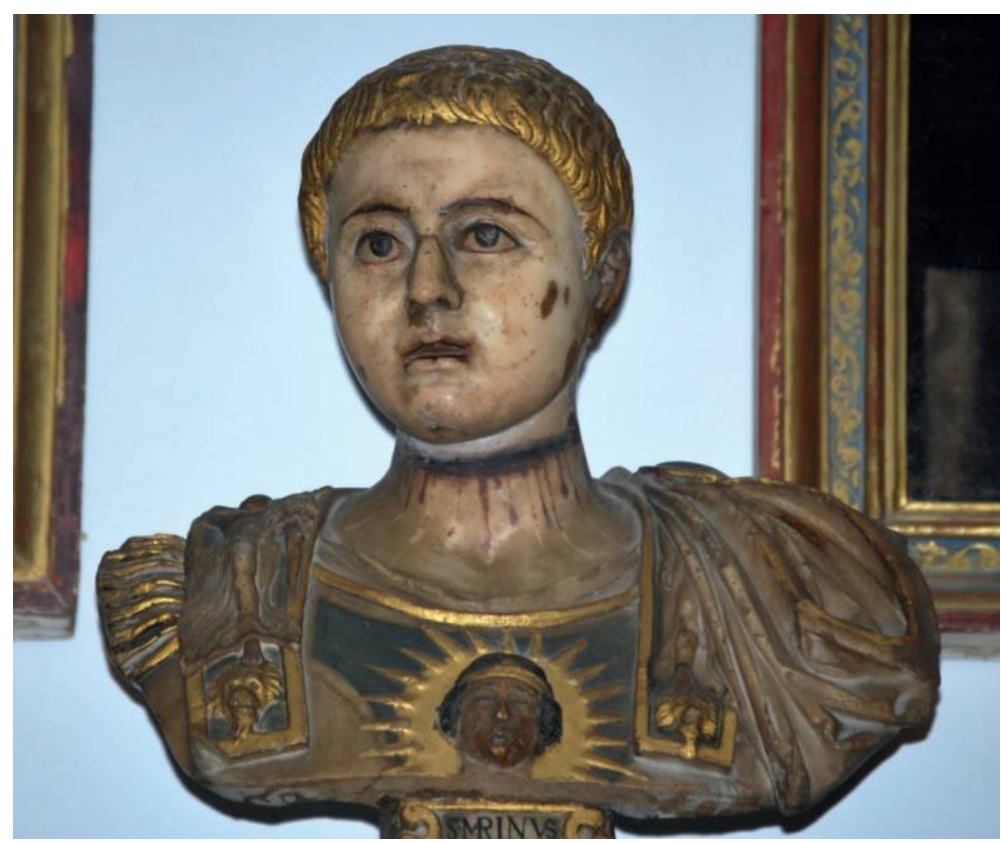

Figura 2. Busto de emperador romano convertido en San Marino, siglo II-III d.c, Colegio del Patriarca, Valencia. Fuente: (C) David Gimilio.

Ya en el siglo siguiente Felipe IV, quizás emulando a lo que había hecho Francisco I en el castillo de Fontainebleau y como estaban haciendo sus contemporáneos Carlos I de Inglaterra o Luis XIII de Francia, envió a Diego Velázquez ${ }^{20}$ a Italia "con embajada extraordinaria para comprar pinturas originales y estatuas antiguas y vaciar algunas de las más celebradas" ${ }^{21}$. Como es sabido, Velázquez tuvo problemas para comprar originales de escultura clásica y solo llegaron a Madrid vaciados de aquellas obras, entre ellas el famosísimo Hércules Farnese y Flora ${ }^{22}$ o el Laocoonte, el Apolo, Antínoo, el Nilo, Cleopatra, la Venus de Medici, los Luchadores y un grupo de las Niobides, todos de la colección del

20 El profesor Rodríguez de Ceballos apunta que, aunque Velázquez no era escultor, ni tenía un conocimiento sólido y diferenciado sobre la escultura clásica, el contacto adquirido con ella, al tener que seleccionar las estatuas que deseaba copiar en bronce o yeso, dispersas por algunas de las mejores colecciones romanas, debió de proporcionarle un gran entendimiento en este tema y dar muestras de haber asimilado composiciones clásicas. Se observa después de este segundo viaje cierta influencia en sus propias composiciones. Así en el Marte del Museo del Prado se percibe la huella de esculturas como el Ares Ludovisi o en la Venus del Espejo se nota la influencia del Hermafrodita y en el Mercurio y Argos la figura del segundo repite la postura del Galo moribundo. Esta influencia está fundamentada porque todas estas esculturas clásicas citadas fueron mandadas a copiar por el propio Velázquez, que las estudiaría de primera mano. Alfonso Rodríguez de Ceballos, "Velázquez y la escultura clásica: el segundo viaje a Italia”, en Velázquez: esculturas para el Alcázar (Madrid: Real Academia de Bellas Artes de San Fernando, 2007), 51.

21 Gloria Mora y Beatrice Cacciotti, "Coleccionismo de antigüedades y recepción del clasicismo. Relaciones entre Italia y España en el siglo XVIII”, Hispania 56, no. 192 (2019): 65. Como recuerda Alfonso Rodríguez de Ceballos posiblemente los vaciados que trajo finalmente Velázquez no le entusiasmaron como tales sino únicamente como piezas decorativas. Rodríguez de Ceballos, "Velázquez y la escultura clásica...”, 32.

22 Cuyos originales estaban entonces en el palacio Farnese y cuyas copias en yeso decoran hoy el ingreso de la Academia de San Fernando de Madrid. 
Belvedere, así como el Espinario del Campidoglio ${ }^{23}$. Parece que no era tarea fácil comprar esculturas clásicas en Roma, pues Urbano VIII había prohibido taxativamente su exportación en 1636 y el pontífice de entonces, Inocencio X, no daba ni siquiera facilidades para sacar moldes de estatuas antiguas ${ }^{24}$.

El objetivo de la misión de Velázquez era dotar al viejo Alcázar de unas salas de representación adecuadas al lugar que España ocupaba entre las naciones del viejo continente ${ }^{25}$ y de un aparato iconográfico que ayudara a potenciar la imagen de la Monarquía. Sabemos que el proceso de copiado de estas esculturas clásicas fue farragoso debido a las diferentes trabas con las que Velázquez se fue encontrando, pero por fin Orazio Albrizzi se comprometió a:

Formar tres estatuas que son de mármol y están en el jardín de Belvedere, a saber el Nilo; el Apolo y el Antinoo, haciendo de cada una de ellas un vaciado de yeso y también un relieve (un molde de yeso y también un vaciado) de cada una dentro de los mismos vaciados (...) los cuales vaciados y relieves sean tan fuertes que permitan incluso su transporte a España ${ }^{26}$.

Ya con la nueva casa reinante en el XVIII, Felipe V mostró una gran afición a la escultura antigua, quizás heredada de la corte versallesca de su abuelo Luis XIV "en donde el interés por procurarse esculturas antiguas pasó de ser una concesión al gusto regio a trocarse objeto de acción política” ${ }^{27}$. Así en 1725, con suerte y buenos agentes comerciales, se hizo con la célebre colección de escultura clásica de Cristina de Suecia que su abuelo no pudo conseguir. Casi toda la colección se componía de originales romanos obtenidos de las excavaciones que Cristina de Suecia había patrocinado unas décadas atrás en la propia Roma o bien compradas directamente a anticuarios de la época. Entre estas 157 piezas destacan el Diadumeno, la Ariadna, Fortuna, Hipnos, Heracles, Júpiter portador de la Egida, Leda o la Venus del Delfín, la mayoría de ellas actualmente en el Prado 28 . A esta gran colección habría que sumar la que se compró a la duquesa de Alba, Catalina de Haro Guzmán, heredada de su padre el séptimo marqués del Carpio y reunidas básicamente durante su estancia italiana como embajador en Roma.

Los sucesores de Felipe V, Fernando VI y Carlos III mantuvieron este interés por la estatuaria clásica. Durante esta época se podrían incluir también los trabajos

23 Aunque pensado para el Alcázar de Madrid actualmente está en el Museo del Prado. En esa época en España ya había una copia en el jardín de la Isla del Real Palacio de Aranjuez, regalo del cardenal Giovanni Ricci a Felipe II en 1561.

24 Rodríguez de Ceballos, "Velázquez y la escultura clásica...”, 37. Aunque Inocencio X era más favorable a España que su predecesor, el embajador Rodrigo Díaz de Vivar y Mendoza, duque del Infantado tuvo que solicitar por dos veces, el permiso para que a Velázquez se le facilitase sacar las copias del Belvedere vaticano y de otras colecciones pontificias en la ciudad.

25 David García Cueto, "Don Diego de Aragón, IV Duque de Terranova, y el envío de esculturas para Felipe IV durante su embajada en Roma (1654-1657)”, Archivo Español de Arte 78, no. 311 (2005): 317.

26 Rodríguez de Ceballos, “Velázquez y la escultura clásica...”, 42.

27 Juan Luis González García y Mónica Riaza de los Mozos, "Del saber de la Academia al gusto del amateur: las colecciones de pintura y escultura clásica de Felipe V”, en El arte en la corte de Felipe V (Madrid: Fundación Caja de Madrid, 2002), 185.

$28 \quad$ Ibid., 186. 
realizados por la Real Academia de la Historia y las campañas para el estudio de las antigüedades en España del Marqués de Valdeflores ${ }^{29}$.

\section{La influencia de las esculturas clásicas durante la época Moderna en España}

En la España moderna, la cultura de la mitología clásica y pagana no estaba especialmente difundida entre los pintores y escultores, generalmente dedicados a géneros como el religioso, el retrato u otros más minoritarios como el bodegón o el paisaje.

Eso no quiere decir que no existieran pintores con conocimiento del clasicismo y en concreto de la mitología. Existen ejemplos paradigmáticos como el de Alonso $\mathrm{Cano}^{30}$, en cuyo repertorio de dibujos conservamos algunos de esta temática como, por ejemplo, Venus, Cupido y Sátiro realizado entre $1645-1650^{31}$. En este magnífico dibujo a tinta podemos comprobar el conocimiento que tenía Cano de la antigüedad clásica, como recordó Ceán Bermúdez: “pues, aunque había algunas estatuas del buen tiempo de los romanos en los jardines del palacio del duque de Alcalá, que llaman casa de Pilatos, estaban cerrados. Bien que no faltó profesor andaluz, el granadino Alonso Cano, que tuvo modo de introducirse en ellos porque era muy osado y las copió”32. Sabemos también como el granadino, cuando huyó de Madrid en torno a 1644 por las sospechas en la muerte de su esposa, dejó en la hospedería de la Cartuja de Portaceli de Valencia un importante acopio de libros y estampas que había reunido, lo que nos da idea de que era un personaje con cierto bagaje intelectual $^{33}$.

Dibujos como Ninfa con cántaro de agua (fig. 3), o querubines denotan ese conocimiento de lo clásico que sin duda habría observado de primera mano en las esculturas de las colecciones reales durante su estancia en Madrid. También es interesante, por la combinación de elementos clásicos con cristianos o contemporáneos, el dibujo del Triunfo de Apolo datado hacia $1649^{34}$. Realizado en pluma y tinta parda oscura, que se ha relacionado con su colaboración para la entrada real en Madrid de Mariana de Austria. En él, Apolo, con un nimbo cristífero alrededor de su cabeza, se apoya sobre una columna, y, rodeado de putti, es coronado por dos de ellos mostrados como ángeles.

El basamento muestra la típica ménsula de hoja canesca que popularizará para sus retablos ${ }^{35}$. Otro dibujo, adquirido por el Museo del Prado de Desnudo femenino realizado encima de una traza arquitectónica de un arco, lo relacionó Delfín

\footnotetext{
29 Sobre esta cuestión se puede consultar José Miguel Morales Folguera, Arte clásico y académico en Málaga (Málaga: Centro de Publicaciones de la Diputación de Málaga, 1994), 13-32.

30 Muy interesante para conocer esta relación es Benito Navarrete Prieto, “Alonso Cano y la tradición clásica “, Ars magazine: revista de arte y coleccionismo, no. 41 (2019): 59-69.

31 Conservado en la Galleria degli Uffizi de Florencia con el no. de inventario 10260S.

32 Juan Agustín Ceán Bermúdez, Diálogo sobre el arte de la pintura (1819), 31-32.

33 Navarrete Prieto, “Alonso Cano y la tradición clásica...”, 60.

34 Mide 295 x 202 mm. Se encuentra en la Biblioteca Nacional de Madrid con el no. de inventario B. 234.

35 Para saber más de este tema se puede consultar Zahira Véliz, Alonso Cano, 1601-1667: dibujos: catálogo razonado (Santander: Fundación Marcelino Botín, 2011).
} 
Rodríguez con la escultura manierista de Ninfa dormida que perteneció al duque de Alcalá, con lo que viene a confirmar esa imbricación entre escultura y diseño ${ }^{36}$.

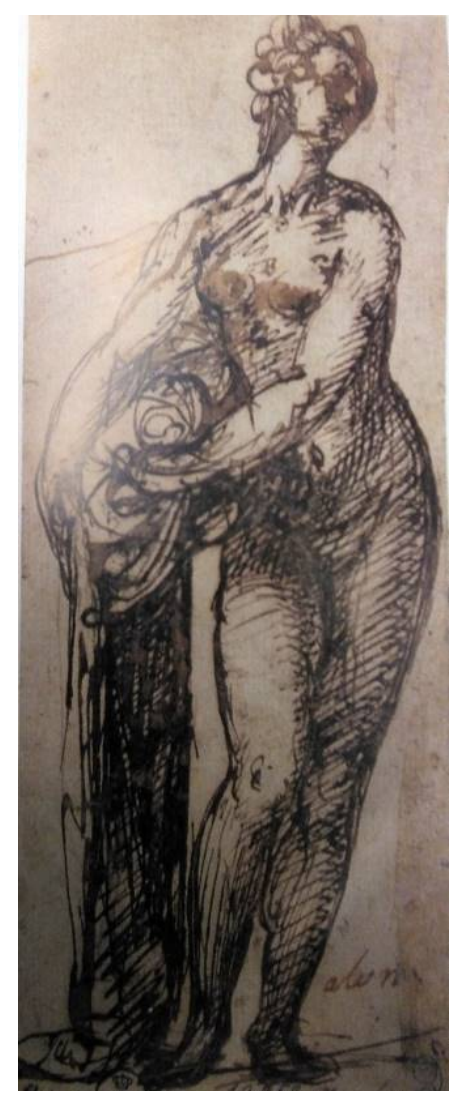

Figura 3. Ninfa con cántaro de agua, dibujo de Alonso Cano. Fuente: Zahira Véliz, Alonso Cano, 1601-1667: dibujos: catálogo razonado.

El taller del artista en España y concretamente en Andalucía durante la época Moderna todavía tenía un carácter casero, al estar instalado en su domicilio. Estaba distribuido habitualmente en dos zonas: el obrador, donde se almacenaban las herramientas y se realizaban trabajos mecánicos como la talla y el ensamblaje, y el "studio" del maestro, generalmente anexo, donde se realizaban las trazas y se conservaban los modelos y copias de esculturas clásicas, amén de grabados, estampas o dibujos, y por supuesto la biblioteca.

El escultor abulense residente en Sevilla Jerónimo Hernández poseía unas 350 estampas de grabados centroeuropeos e italianos ${ }^{37}$. Es revelador el aprecio que existía por los dibujos o las copias de obras de originales de grandes maestros, en

\footnotetext{
36 Navarrete Prieto, “Alonso Cano y la tradición clásica...”, 64.

37 Jesús Miguel Palomero Páramo, El retablo sevillano del Renacimiento: análisis y evolución (1560-1629) (Sevilla: Excma. Diputación Provincial de Sevilla, 1983), 63.
} 
especial por las de Miguel Ángel, del cual en Sevilla se poseyó algún dibujo original que fue muy apreciado, como “el Ganimedes”.

Gracias a la teoría impresa y a la ilustración grabada, los temas artísticos fueron internacionalizados por primera vez desde los centros difusores como los Países Bajos, Alemania, Francia e Italia. Como recuerda Elena Escudero: "Las estampas no tardaron en inundar el panorama artístico europeo, convirtiéndose en reclamo para humanistas, tratadistas, diletantes, devotos y artistas"38.

Debemos tener en cuenta que, salvo contadas excepciones como las de aquellos que originarios de Castilla, Flandes o Francia emigran a Andalucía o los que acometieron la aventura de pasar a los nuevos territorios de Ultramar, la mayoría de los escultores no tenían la oportunidad de viajar. Esto nos permite imaginar la dificultad de acceso a los originales de esculturas clásicas, dado que sólo una élite de estos escultores habría visitado zonas especialmente ricas en arte clásico de renombre como Italia. Esto motivó que, por lo general, el acceso habitual a estas esculturas fue a través de dibujos o grabados.

En la biblioteca del monasterio del Escorial, se encontraba el Codex Escurialensis $^{39}$ cuyos dibujos reproducían antigüedades clásicas, preferentemente ruinas, aunque también algunas estatuas clásicas. También se guardaba Desenhos das antigualhas que vio e retratou de sua mano, manuscrito de Francisco de Holanda, cortesano de Felipe II, donde estaban dibujadas las célebres estatuas del Belvedere vaticano: el Laooconte ${ }^{40}$, la Ariadna, -conocida como Cleopatra entonces-, y el Apolo ${ }^{41}$. Estas obras estaban resguardadas en colecciones o bibliotecas reales de difícil acceso para los escultores y artistas en general y por lo tanto de escasa repercusión en el panorama cotidiano de la elaboración de imágenes.

En cambio, entre los libros más difundidos en esta época y en el siglo posterior destacaron los de Antonio Lafreri, Cavalleris, y sobre todo el de Philippe Thomasin, Antiquarum Statuarum Urbis Romae, editado en 1638. Se trataba de una especie de álbum donde se habían seleccionado unas cien estatuas clásicas de las diferentes colecciones que había en Roma y que eran las más atractivas para el gusto barroco del momento.

\section{La influencia de modelos clásicos en la representación de algunas iconografías cristianas}

Como recuerda José Policarpo Cruz, "las posibilidades de la copia o emulación no sólo eran directas sino también permitían transliteraciones entre temas paganos y

38 Elena Escuredo Barrado, “A propósito de la influencia de los grabados como fuente de la escultura barroca sevillana: las estampas de los Wierix”, Archivo Hispalense 300-302, no. 99 (2016): 344.

39 El Codex Escurialensis había venido a la Península Ibérica con el escultor florentino Andrea Sansovino y parece que estaba en Portugal desde 1493. Unos años más tarde aparece España quizás gracias a Don Manuel de Portugal en 1498 (que fue a Zaragoza con el arzobispo de Sevilla don Diego Hurtado de Mendoza, además de Guadalajara y Sevilla Tambien visitó Toledo en 1500. Para regresar a Florencia en 1501. Miguel Falomir Faus y Fernando Marías Franco, "El primer viaje a Italia del Marqués del Zenete", Anuario del Departamento de Historia y Teoría del Arte (U.A.M.) (1994): 6: 108.

$40 \quad$ La copia de este por desgracia quedó destruida en el incendio del Alcázar de 1734.

41 Rodríguez de Ceballos, “Velázquez y la escultura clásica...”, 35. 
cristianos”42. Así hay tipos iconográficos que tienen su posible origen en la antigüedad clásica. Dentro de dichos asuntos tuvo una especial popularidad el de los putti readaptados en ángeles. Es ejemplo destacable el sarcófago de Amor y Psique, conservado en la iglesia de Santa Agnese fuori le mure de Roma y fechado hacia el siglo III. Representa una pareja de putti que sostienen un medallón o tondo con el retrato del difunto quizás pensando en su nueva reinterpretación cristiana como ángeles al destinarse a ser conservado en un entorno sacro.

Durante el Renacimiento y el Manierismo, el tema de la muerte se enriquece, incorporando elementos como el humo, el viento, o la imagen de un niño, asociada a la representación de las ideas de la religión antigua. Buen ejemplo de ello es la producción de un tipo iconográfico de alto valor retorico y dramático por su doble relación con la pasión de Cristo y con la vanitas barroca: el Niño Jesús dormido. Como recuerda Núñez Fuster ${ }^{43}$, en la antigüedad clásica era habitual la ternura ante el niño dormido o el lamento ante el niño muerto, especialmente entre determinadas elites con especial formación y sensibilidad hacia los niños, tal y como podemos comprobar en algunos testimonios escritos de la época.

Podemos encontrar un origen iconográfico por tanto al Niño Jesús dormido en el tipo helenístico de Eros dormido sobre un cráneo, de significación claramente fúnebre en la antigüedad ${ }^{44}$. La mayoría de las veces el Niño está recostado sobre una cruz, relacionándolo a su vez con la representación de Cristo difunto ${ }^{45}$. Un ejemplo interesante a reseñar es el Eros dormido sobre las armas de Hércules del Museo Arqueológico Nacional. Se trata de una pieza de época Flavia procedente de Elche $^{46}$ que demuestra las altas calidades de la escultura romana y presenta una curiosa semejanza con las posteriores representaciones del Niño Jesús (fig. 4). A ello contribuye la propia personalidad de Eros que hacía reinar la calma cuando dormía. Se le muestra echado sobre sus atributos (como luego será habitual en los niños Jesús) o sea sobre una piel de cabra, con la cabeza apoyada sobre el brazo izquierdo, en cuya mano podía llevar dos adormideras que en ocasiones puede llevar a confundirlo con Hipnos, el dios del sueño. También tiene mucha calidad el Eros dormido del Museo del Prado ${ }^{47}$ de un taller romano. A veces, Eros también incorpora el arco y las flechas ${ }^{48}$.

Dentro de ejemplos ya cristianos podemos destacar por ejemplo la escultura que estudió hace unos años el profesor Gómez Piñol atribuyéndola al quehacer de Jerónimo Hernández y que actualmente se encuentra en la ermita de Nuestra

42 José Policarpo Cruz Cabrera, "Grabado, dibujo, escultura y pintura. Intercambios y trasvases visuales en la plástica barroca granadina”, en Arte y cultura en la Granada renacentista y barroca: relaciones e influencias (Granada: Universidad de Granada, 2014), 54.

43 Joaquín Núñez Fuster, Introducción al estudio del origen, formación y desarrollo de las representaciones angélicas infantiles en el arte del renacimiento italiano y de los países transalpinos. Trabajo realizado para la suficiencia investigadora (DEA: Sevilla, 2005), 121.

44 Cruz Cabrera, "Grabado, dibujo, escultura y pintura...”, 54.

45 Agustín Martínez Peláez, “Cementerios, tumbas y el espacio sagrado de la muerte” en Actas de las jornadas Forma y función en espacios sagrados (Madrid: Universidad Rey Juan Carlos, 2019), 9.

46 Tiene unas medidas de 43,50 cm de longitud y 27,30 cm de ancho y núm. de inventario 17459. Sobre esta temática se puede consultar Mercedes Oria Segura, "Jugando a ser dioses: Heracliscos y otros dioses niños en la estatuaria hispana”, BSAA 63 (1997): 115-137.

47 Fechado hacia el 120-130 d.c, mármol, 48 x $30 \mathrm{~cm}$.

48 Fernando Pérez Suescun, Catálogo de la exposición Arte y mito, los dioses en el Prado (Madrid: Museo del Prado, 2018), 63. 
Señora del Valle en Manzanilla (Huelva). Se trata de una talla en la que el Niño aparece sobre una cruz mientras recuesta su cabeza sobre una calavera. También son destacables el Niño Jesús dormido sobre la calavera que se encuentra en el convento de madres justinianas de Cuenca o el del convento sevillano de San José del Carmen, popularmente llamado de las Teresas. Aquí aportamos también uno en plomo de una colección particular de Sevilla (fig. 5) como ejemplo de una serie de niños Jesús muy difundidos por la Península y fechables a finales del siglo XVI ${ }^{49}$.

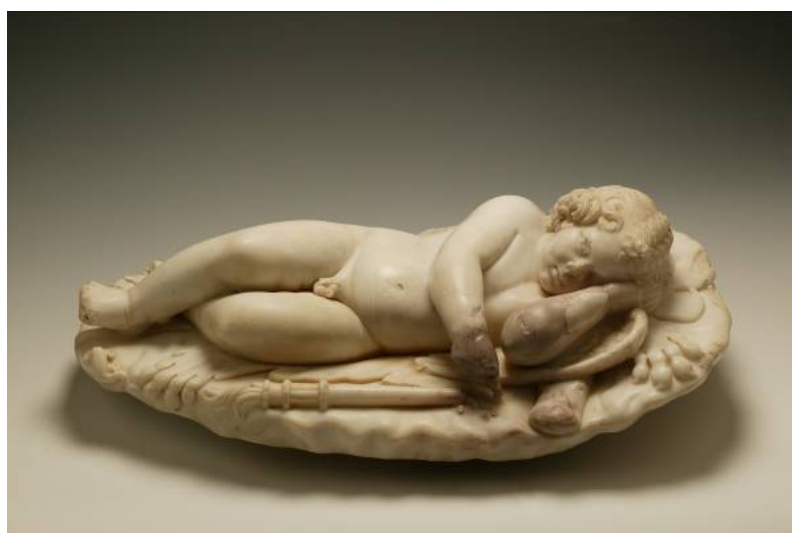

Figura 4. Eros dormido sobre las armas de Hércules, Museo Arqueológico Nacional. Fuente: () Miguel Ángel Otero

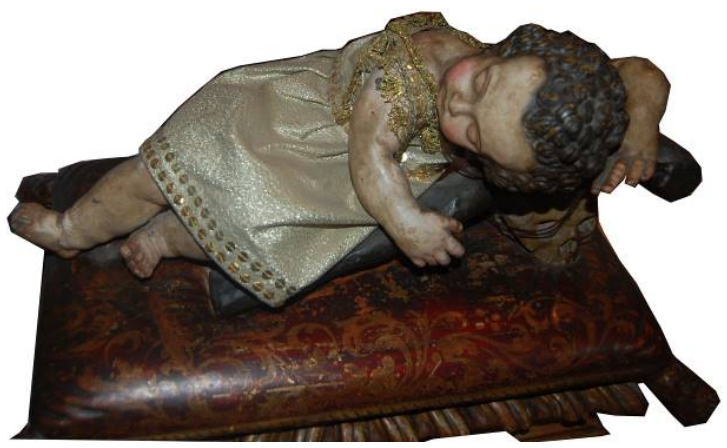

Figura 5. Niño Jesús dormido sobre una cruz, plomo, anónimo, Colección particular.

Fuente: ㄷ Jesús Porres Benavides.

49 En el Museo Nacional de Escultura tienen por ejemplo una catalogada como del taller de Juan Martínez Montañés. Estas imágenes, en las que "le pintan durmiendo sobre la Cruz, poniéndole por almohada el cráneo, o calavera de un hombre", como señalara Fray Juan Interián de Ayala en su tratado "El pintor christiano y erudito" (Madrid, 1782), "no tanto pertenecen a la historia, quanto son objeto de piadosas meditaciones". Miguel Ángel Marcos Villán, "Niño Jesús dormido sobre cruz”, en Museo Nacional de Escultura VI: La escala reducida, dir Jesús Urrea Fernández (Valladolid: Museo Nacional de Escultura 2008), 24-25. 
Por último, podemos reseñar el denominado Niño de la Pasión ${ }^{50}$ del Museo Lázaro Galdiano de Madrid, una escultura en madera policromada y estofada ${ }^{51}$. Se encuentra recostado sobre la cruz y en su momento tendría el cráneo o calavera de Adán, sobre el que apoya el brazo. Esta prefiguración de la Pasión está muy presente en la España contrarreformista.

Una de las más bellas representaciones pictóricas de este tema es la que está atribuida a Bartolomé Esteban Murillo en el Museo del Prado ${ }^{52}$. Como decíamos antes, tradicionalmente se ha considerado que estas imágenes son una reinterpretación cristiana del tema del Eros dormido, aunque del pintor holandés Martin van Heemskerck (1498-1574) nos ha llegado una versión en clave de vanitas -Nascendo Moritur- de gran repercusión en el mundo nórdico renacentista, y que bien pudo conocer el pintor sevillano ${ }^{53}$. Quizás, como recuerda José Luis Requena, entre estos antecedentes podríamos citar también un grabado del pintor boloñés Giacomo Francia (Ca. 1486-1557) que representa al Niño Jesús dormido sobre una gran cruz. Este piadoso tema gozó de gran popularidad entre los pintores boloñeses del Barroco como Guido Reni, Orazio Gentileschi o Francesco Albani y halló en el grabado uno de los medios más rápidos de difusión.

Otro tipo iconográfico como el Niño Jesús adolescente o infante que se pincha con una espina de la corona de la Pasión parece tener su referente en imágenes clásicas como El Espinario ${ }^{54}$ (fig. 6). Ya sabemos cómo desde el mundo clásico griego, y sobre todo desde época helenística y romana, hubo bastantes representaciones infantiles, a veces aisladas y otras veces acompañando a otras esculturas o grupos como complemento de escenas históricas o mitológicas ${ }^{55}$. En honor a la verdad son relativamente escasas las imágenes infantiles que han llegado a nosotros provenientes del arte clásico griego anterior a la época helenística. En general, son representaciones infantiles de seres mitológicos y excepcionalmente niños idealizados en conmemoraciones funerarias. Esta imagen del espinario, según Núñez Fuster, es una representación cotidiana de temas de exaltación atlética tan apreciados en el arte helenístico. Aquí el joven que después de la carrera se

50 Emilio Camps Cazorla, Inventario del Museo Lázaro Galdiano. Madrid, 1948-1950; José Lázaro, La Colección Lázaro de Madrid (Madrid: La España Moderna, 1926); José Camón Aznar, Guía Abreviada del Museo Lázaro Galdiano (Madrid, 1951).

51 Dimensiones de la base, máximas, $58 \mathrm{~cm}$ de largo por $36 \mathrm{~cm}$ de ancho. Base con moldura de ovas, antigua, sobre zócalo con moldura de bronce.

52 Óleo sobre lienzo, 63 x $88 \mathrm{~cm}$.

53 José Luis Requena Bravo de Laguna, “Algunas consideraciones iconográficas sobre la prefiguración de la Pasión de Cristo en su Santa Infancia en la pintura barroca andaluza”, en "Aquenda et allende”: Obras singulares de la Navidad en la Granada moderna (Siglos XV-XVIII) (Granada: Diputación de Granada, 2014), 63-85.

54 En el Museo del Prado (Madrid) poseen una copia del original, que mide también $73 \mathrm{~cm}$. de altura, y se encuentra en el Museo Capitolino de Roma. En él llama la atención el estilo arcaico de la cabeza en contraste con el naturalismo y espontaneidad del cuerpo. Se creía que fue adquirida por Velázquez durante su segundo viaje a Italia (1648-51), aunque hoy se presume que fue realizado en Madrid a partir del Espinario que, atribuido a Guglielmo della Porta y fechado hacia 1560, estaba en Aranjuez, donde aún se encuentra. Rosario Coppel Aréizaga, Catálogo de la Escultura de Época Moderna. Siglos XVI-XVIII (Madrid: Museo Nacional del Prado, 1998), 248 y 249.

55 Rafael Ramos Sosa, "De Malinas a Lima, un largo viaje para un Niño perdido. Notas sobre el Niño Jesús montañesino a propósito de nuevas obras en el Perú”, en Actas del Coloquio Internacional El Niño Jesús y la infancia en las artes plásticas, siglos XV al XVII. IV Centenario del Niño Jesús del Sagrario, 1606-2006 (Sevilla: Pontificia Archicofradía del Santísimo Sacramento del Sagrario de la Catedral de Sevilla, 2010 ), 315. 
sienta para arrancarse una espina ha sido sustituido por un adolescente de formas "poco atléticas".
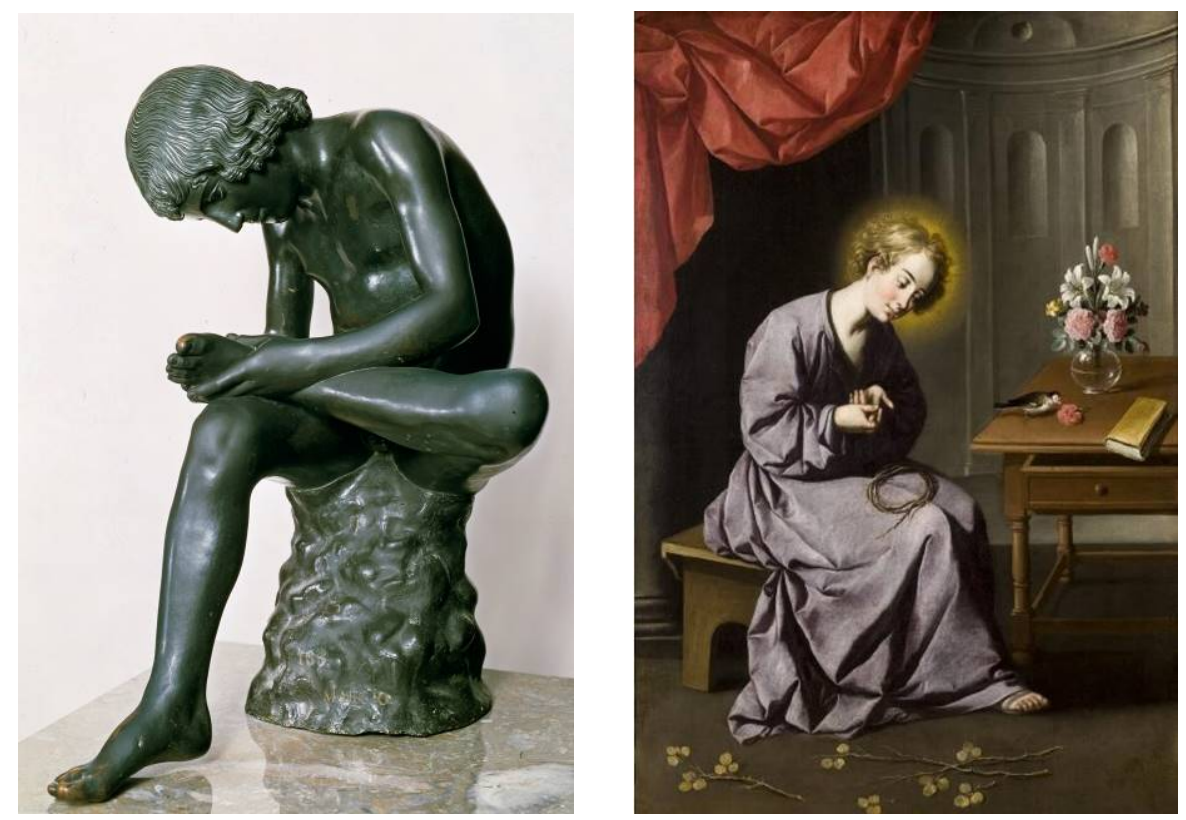

Figuras 6 y 7. El espinario, Cesare Sebastián, hacia 1650, copia de un original romano (C) Museo Nacional del Prado. El niño de la espina, Francisco de Zurbarán1630/1650. Fuente: (C) Museo de Bellas Artes de Sevilla.

Sin duda el que mejor recreará esta iconografía en pintura durante el barroco será Francisco de Zurbarán, como en su "casa de Nazaret, de la que se conocen tres versiones, o en las que aparece de manera individualizada (fig. 7). En ellas se muestra a Jesús mirando fijamente el dedo sangrante que se acaba de pinchar con la corona de espinas que tiene en su regazo. Este tema es un episodio premonitorio de la Pasión, pintado por el artista de Fuente de Cantos en varias ocasiones y que narra Ludolfo de Sajonia, el Cartujano, en su libro Vita Christi, escrito en latín hacia 1350 y traducido al castellano en Sevilla en $1537^{56}$. La sangre que aparece en el dedo del Niño que se acaba de pinchar vendría a ser una premonición de la pasión del propio Cristo.

Hace unos años el profesor Gómez Piñol también relacionó algunos tipos iconográficos como el Himnos y Tanathos como arquetipos para los niños Jesús llorones. Así según él, un "Niño Jesús lloroso" 57 de la clausura del convento de

56 Enrique Valdivieso González, "Una Virgen niña hilando y un Niño de la Espina de Juan Simón Gutiérrez”, Laboratorio de Arte 15, (2002): 396. Sobre la relación del Cartujano con las artes plásticas, véase también Lluis Ramon i Ferrer, "La Vita Christi de Ludolfo de Sajonia y la Imago pietatis, un ejemplo de complementariedad discursiva”, en Christ, Mary and the saints, Reading Religious Subjects in Medieval and Renaissance Spain (Leiden-Boston: Brill, 2018).

57 Es una talla de unos $30 \mathrm{~cm}$. aprox. y habitualmente se muestra vestido. Emilio Gómez Piñol, "Las atribuciones en el estudio de la escultura: nuevas propuestas y reflexiones sobre obras de la escuela sevillana 
San Leandro de Sevilla al que la comunidad llama cariñosamente "quitapesares", habría que identificarlo correctamente con un genio funerario infantil seguramente proveniente de algún retablo. Este tipo de figuras, como recuerda Gómez Piñol, se relacionan con relieves del mundo antiguo, después asociado durante el Renacimiento "con diversas variantes iconográficas relacionadas con el memento mori o reflexión sobre la transitoriedad de las cosas mundanas y el ineluctable encuentro con la muerte" 58 . Efectivamente la imagen está llorando agarrada al extremo de una antorcha invertida en actitud de apagar sus llamas contra el pedestal. De una manera algo teatral aleja la otra mano y parece que está conmocionado por una "travesura recién hecha”. También recalca la semejanza con algunos ángeles del retablo de San Juan Evangelista del convento de Santa Paula que realizó Alonso Cano.

Esta figura recuerda a otra que estaba desde un siglo antes en la ciudad en el sepulcro del adelantado don Pedro Enríquez en la Cartuja de las Cuevas de Sevilla. Esta obra había sido realizada por el escultor italiano Antonio $\mathrm{M}^{\mathrm{a}}$ Aprile hacia 1525 en Génova. Dicha influencia no sería para nada disparatada ${ }^{59}$, ya que, como hemos dicho, algunas fuentes como la de Ceán apuntan quizás de forma un poco novelada, a que Cano conociera las colecciones de escultura clásica existentes en la "casa de Pilatos" y que visitara su mausoleo en la Cartuja. Otra obra parecida se encuentra en la iglesia parroquial de San Pedro en Arcos de la Frontera (Cádiz) travestido en un pastorcito "divino" que acompaña a la Divina Pastora.

Como ya plantea el propio Gómez Piñol, aún no tenemos respuesta a los interrogantes sobre el momento en que este tipo iconográfico pasó a ser cristianizado y cómo se interpretó un atributo pagano como las teas invertidas en un contexto cristiano, pero dicho fenómeno se produce en "el agitado crisol de tendencias artísticas en conjunción y oposición que se debatían en la Sevilla del primer tercio del siglo XVII, donde hubo una plena asimilación del clasicismo, junto a anacronismos medievales conjugado en un reciente barroco de "hondas raíces vernáculas" ${ }^{60}$.

Igualmente podemos encontrar algún precedente a la actitud naturalista y humana desarrollada con la figura de San José a partir de la Contrarreforma, especialmente tras el impulso a su devoción por parte de Teresa de Jesús. No sabemos si Alonso Cano, cuando plantea su San José del convento del Ángel Custodio de Granada (fig. 8), tiene presente la imagen atribuida a Lisipo y las numerosas copias que de este original griego se hicieron en época helenística y romana del Sileno con Dionisos niño, como la conservada en la Gliptoteca de Múnich y fechada hacia el 310-300 a.C., pero podemos encontrar ciertos paralelismos $^{61}$. Representa al preceptor de Dionisos (Baco) el viejo y borracho

de los siglos XVI y XVII”, en Nuevas perspectivas críticas sobre historia de la escultura sevillana (Sevilla: Junta de Andalucía, 2007), 97.

58 Cf. Ibid.,98.

59 Otra obra renacentista de un geniecillo transmutado en ángel está en la capilla de San Gregorio de la catedral de Sevilla, pero como recuerda Gómez Piñol, salvo en lo iconográfico nada tienen que ver formalmente con la obra genovesa ni con el “niño” doliente de San Leandro.

60 Gómez Piñol, “Las atribuciones en el estudio de la escultura...”, 106.

61 Estas influencias de Sileno con Baco niño en obras religiosas también las detectó por ejemplo Romero Torres en el San Antonio de Padua en la sillería de la catedral de Málaga o el San José comentado. José Luis Romero Torres, "Pedro de Mena, el coro de la catedral de Málaga y algunas fuentes de inspiración”, Cuadernos de los 
sátiro Sileno que lo lleva en brazos para preservarlo de la ira de Hera, esposa de Zeus. El original era un bronce de Lisipo de finales del siglo IV a. C., que conocemos a través de copias romanas como la existente en el Museo del Louvre (fig. 9) ${ }^{62}$. Como comenta José Luis Romero, esta obra tuvo mucha difusión, y hacia 1650 llegó a España un vaciado de escayola para el rey Felipe IV. Parece que Alonso Cano debió conocer esta copia o bien un grabado de esta ${ }^{63}$.
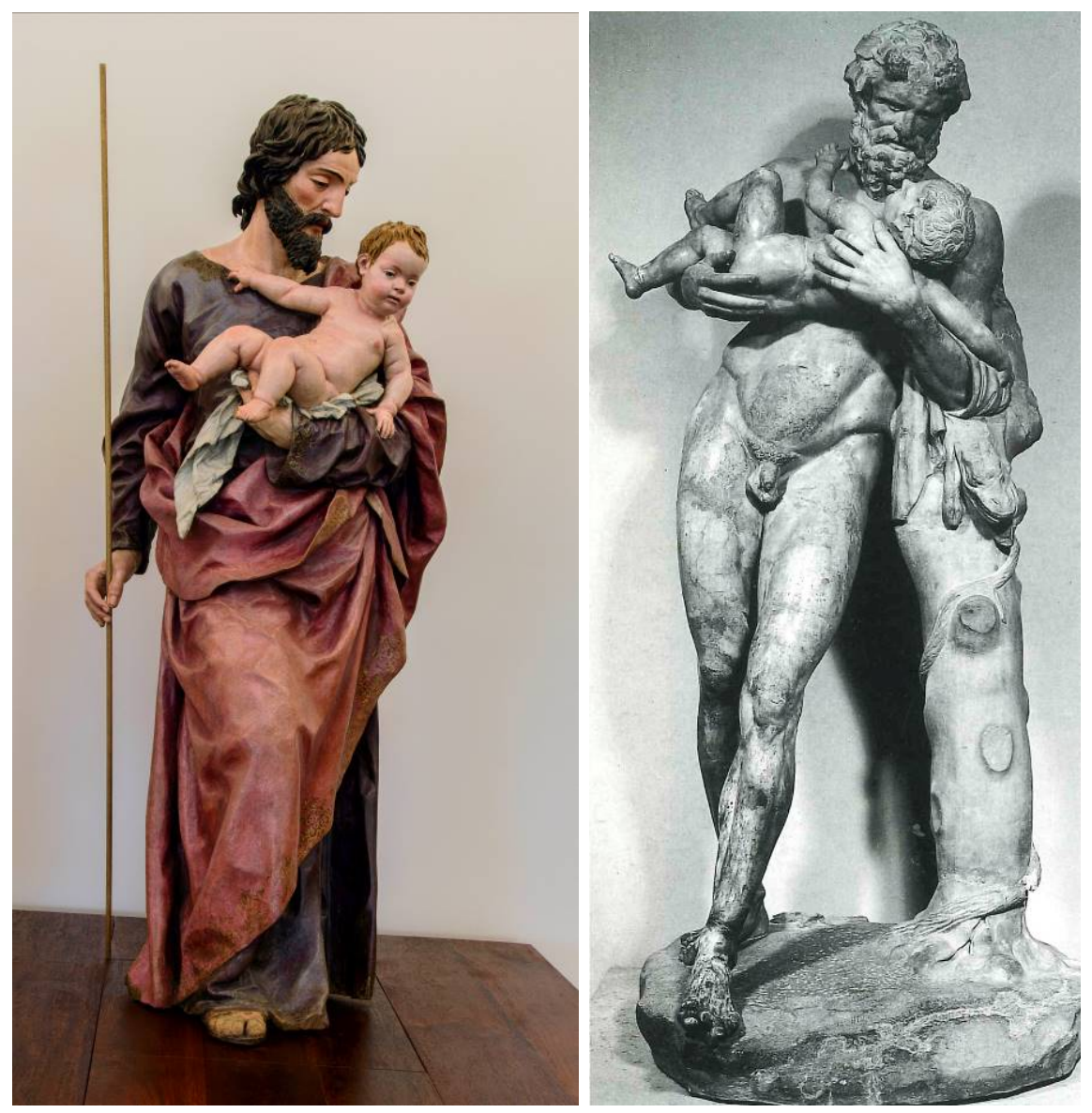

Figuras 8 y 9. San José con el Niño, Alonso Cano 1653-1657. Museo de Bellas Artes de Granada. Sileno con Dionisos niño, copia romana. Fuente: (C) Museo del Louvre.

Amigos de los Museos de Osuna 16 (2014); 97. Pedro de Mena granatensis malacae: [catálogo de la Exposición] Palacio Episcopal de Málaga y Santa Iglesia Catedral Basílica de la Encarnación, 16 de marzo-14 de julio de 2019, (Málaga: Palacio Episcopal, 2019). Es interesante saber cómo en Málaga durante el barroco había alguna colección de escultura clásica. Consultar José Miguel Morales Folguera, "La colección de obras italianas de los condes de Buenavista, 1660-1745”, en XI Congreso CEHA (1998), 202-206.

62 Esta obra se había descubierto en la segunda mitad del siglo XVI y durante el barroco perteneció a la colección Borghese. Romero Torres, “Pedro de Mena, el coro de la catedral de Málaga...”, 97.

63 En la Academia de San Fernando se conserva una copia de la versión del Museo Capitolino. 
Benito Navarrete recuerda que esa relación clásica en Cano no pasó desapercibida a algunos coetáneos del propio Ceán como Fernando Marín que, al contemplar los bustos de Adan y Eva de la catedral de Granada afirmaba que estaban "executadas con tanta eminencia que parecen obra de los griegos" ${ }^{\text {" }}$. También se ha visto la posible influencia en la cabeza de Adán del torso del Ganimedes que a principios del XVII estuvo en los jardines de la Alhambra ${ }^{65}$, o la relación de la de Eva con otras obras clásicas del propio autor como la pintura de Juno descubierta hace unos años.

Otras representaciones infantiles aparecerán por ejemplo en la figura o glorificación de la Tierra entre el Aire y el Agua del Ara Pacis Augustea que, al decir de Blanco Frejeiro: "ofrece el conjunto más importante no solo del arte escultórico augusteo, sino de todo el arte escultórico romano”66. En este relieve Tellus, la Tierra, acoge amorosamente a dos niños pequeños que juegan sobre su madre. Como también ha observado Núñez Fuster, el grupo recuerda la forma con la que se representará posteriormente la virtud de la Caridad cristiana ${ }^{67}$. Es sintomático este tipo de derivaciones que afectarán incluso a la propia imagen de la Virgen a partir del Renacimiento. Así ocurre, por ejemplo, con el relieve de la Virgen con el Niño en la portada de la iglesia de la Anunciación de Sevilla, atribuido por similitudes a Juan Bautista Vázquez $^{68}$. Este relieve de la Anunciación, puede tener un precedente en el realizado por Vázquez para el colegio de las Doncellas de Toledo y sin duda está inspirado por ese clasicismo de raíces italianas característico en él y que se encuentra presente en otros autores como Torrigiano que tanta huella dejó en la ciudad de la Giralda.

Otras obras como el Gran Camafeo de Francia conservado en el gabinete numismático de la Biblioteca Nacional de París desde 1791, representan a una mujer entre los prisioneros con un lactante en sus brazos, lo que podría constituir una anticipación de la representación de la Caridad Romana.

La nueva efigie de Cristo también bebió de la tradición clásica en su formación, ya que no contaba con un antecedente propio y tuvo que ser creada para tal fin. La tradición más ortodoxa y apegada al judaísmo y algunos de los doctores de la Iglesia insistieron en representar un dios pobre de cuerpo y esencia, más en consonancia con lo que trasmitían los Evangelios. Poco a poco se impuso la tradición helenística de los que se iban incorporando a la Iglesia. Se va a ir defendiendo un concepto de Cristo bueno que debía ser consecuentemente bello, gestándose paulatinamente la idea de un Cristo apolíneo. Es interesante esa idea de la reconversión de la figura del héroe pagano a los santos como prototipos en época cristiana y especialmente en la figura de Cristo como el héroe que dio su vida por una causa mayor ${ }^{69}$.

\footnotetext{
64 Navarrete Prieto, “Alonso Cano y la tradición clásica...”, 66.

65 También es interesante en el ámbito granadino la obra del Marqués de Zenete en el Palacio de la Calahorra.

66 Antonio Blanco Frejeiro, Arte Griego (Madrid: CSIC, 1996), 206.

67 Núñez Fuster, Introducción al estudio del origen, formación y desarrollo..., 126.

68 Manuel Gómez-Moreno, La escultura del Renacimiento en España (Florence: Pantheon Casa Editrice, 1931), 90; José Hernández Díaz, Imaginería hispalense del Bajo Renacimiento, (Sevilla: Consejo Superior de Investigaciones Científicas, Instituto ‘Diego Velázquez’, Sección de Sevilla, 1951), 32-33.

69 Ignacio Cano Rivero, el héroe, consultado el 18 de abril de 2020, https://www.youtube.com/watch?v=RnMI5Pr4S4\&t=7s\#MW2020 MuseumWeek ICOM España Consejería de Cultura - Junta de Andalucía Ministerio de Cultura y Deporte
} 
Las primeras representaciones de Cristo serán con el pelo corto e imberbe (muy cercano a las representaciones de Apolo) intentando recrear a una persona joven. Este tipo de representaciones quizás eran cotidianas en la Roma imperial puesto que los filósofos y maestros proliferaban por la ciudad. Apolo es visto como un semejante a Cristo en la lucha contra el mal. Aquí se produce una moralización de la figura del dios griego, porque se le encuentra un sentido dentro del organigrama cristiano.

En la transición del manierismo al naturalismo en Andalucía occidental destaca sin ningún tipo de parangón la figura del escultor alcalaíno Juan Martínez Montañés. Sin duda sus imágenes gozan del pathos, pero sobre todo de las proporciones de las figuras clásicas y el canon de ocho cabezas de Lisipo, lo que le valió el apelativo de "el Lisipo andaluz". Uno de sus mejores discípulos, Juan de Mesa (1583-1627) recreará en algunos de sus crucificados influencias de obras fundamentales de la escultura clásica. Así en su sobresaliente Cristo de la Agonía de Vergara (Guipúzcoa) $)^{70}$ parece que se inspira en el famoso Laooconte (fig. 10), en la forma que se alza el tronco superior y el giro de la cabeza. La verdad es que esta influencia seguramente se produjo de forma indirecta a través de la obra de Gaspar Núñez Delgado (que trabajó en Sevilla entre 1581 y 1606) en las composiciones de Mesa. Así, por ejemplo, en algunos de los cristos de marfil de Núñez Delgado, como el que se conserva en el museo de Indianápolis fechado en 1599, vemos esta inspiración. Como apunta Rodríguez Morales, quizás también pudo inspirarse en el Cristo de la Expiración de Marcos de Cabrera realizado para la Hermandad del Museo en 1575. A su vez ambas influencias vendrían de Miguel Ángel, del que sabemos que circulaban por Sevilla estampas y composiciones extraídas de sus obras ${ }^{71}$.

El tema del Pantocrátor tiene igualmente una clara influencia en la desaparecida escultura de Zeus en Olimpia o por ejemplo la relación entre la iconografía del "Buen Pastor" y Hermes Crióforo (dios protector de los caminos y guía de los viajeros). Este tipo de relaciones entre temas clásicos e iconografías cristianas se puede ver también en otros generos como la pintura, e incluso a la inversa. Aunque no se trate de una pintura andaluza es muy interesante la pintura de Júpiter y Licaón de Jan Cossiers, en el Museo del Prado (fig. 11) ${ }^{72}$. El boceto fue realizado por el propio Rubens y formaba parte de una serie de cuadros que irían para el real sitio de la torre de la Parada, realizados en torno a 1636-1638 aproximadamente, siguiendo la correspondencia entre el Cardenal Infante Don Fernando, gobernador de Flandes, y su hermano el rey Felipe IV. Aquí Licaón, un infausto gobernador de la Arcadia, quiso comprobar la divinidad de Júpiter dándole a comer carne humana. Ovidio narra esta historia en el libro I de Las Metamorfosis (207-243): “Al principio Licaón se rio de sus piadosas plegarias, después dijo: Voy a ver con una prueba clara, si éste es un dios o un mortal, y la verdad será indubitable”. Al poner

70 Aunque también en el crucificado de la Conversión del Buen Ladrón para la cofradía de Monserrat en Sevilla se aprecia estas influencias clásicas.

71 Pacheco se preciaba de tener un dibujo original del florentino, el Rapto de Ganimedes, además de varias miniaturas de Giulio Clovio sobre obras del maestro y una estampa del Cristo Resucitado de Santa María sopra Minerva. Miguel Bago y Quintanilla, Documentos para la Historia del Arte en Andalucía V: Arquitectos, escultores y pintores sevillanos del siglo XVII (Sevilla: Laboratorio de Arte, 1932), 69-70.

72 Fechada hacia 1636-1638. Óleo sobre lienzo y con unas medidas de 120 x $115 \mathrm{~cm}$. 
sobre la mesa el plato con los miembros de un rehén que acababa de matar Júpiter con un rayo partió su casa y convirtió en lobo a Licaón. La figura de Júpiter recuerda vivísimamente a la figura de Cristo, siendo así en este ejemplo la transmutación a la inversa.

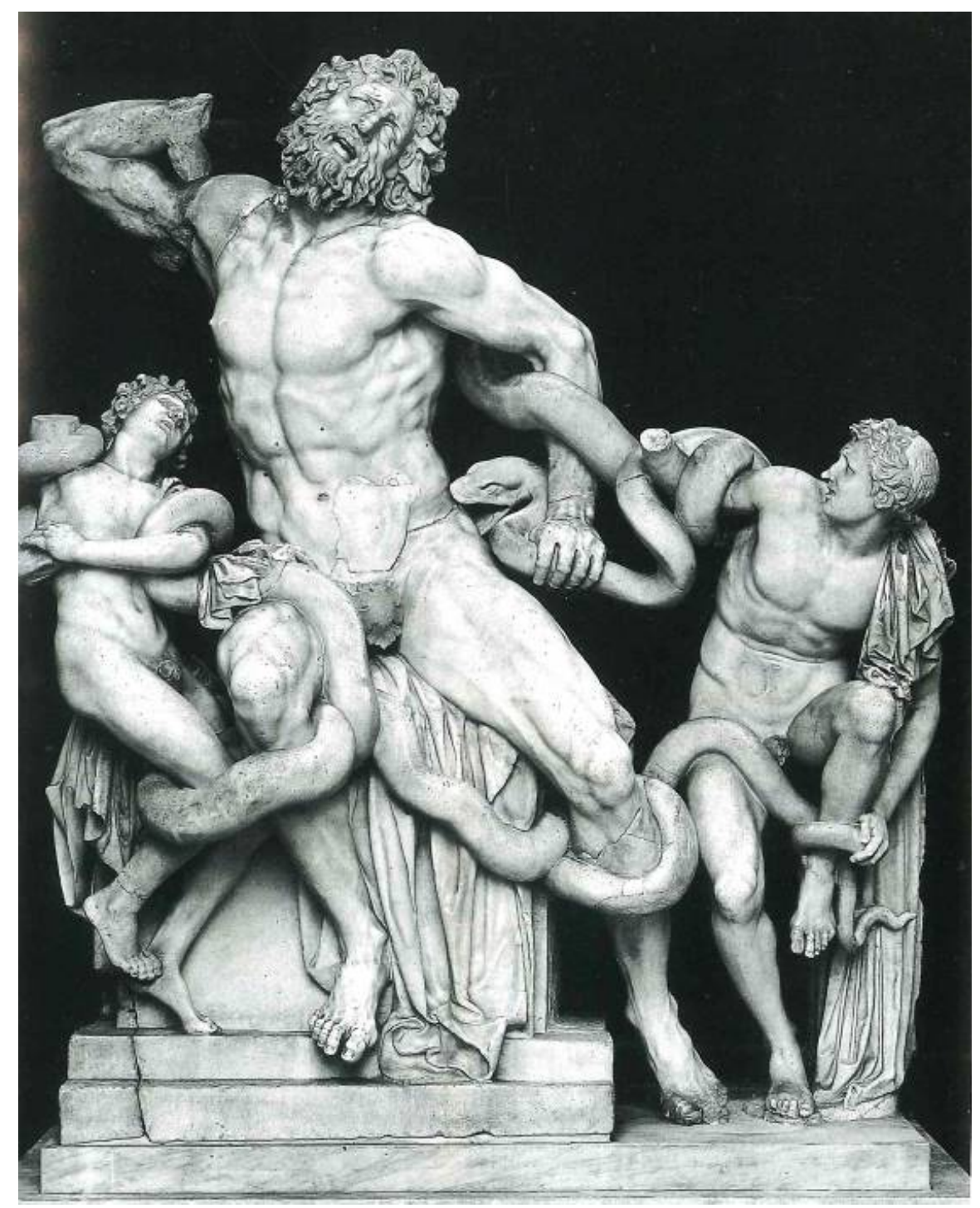

Figura 10. Laocoonte y sus hijos. Agesandro, Polidoro y Atenodoro de Rodas. Fuente: (C) Museo Vaticano, Roma. 


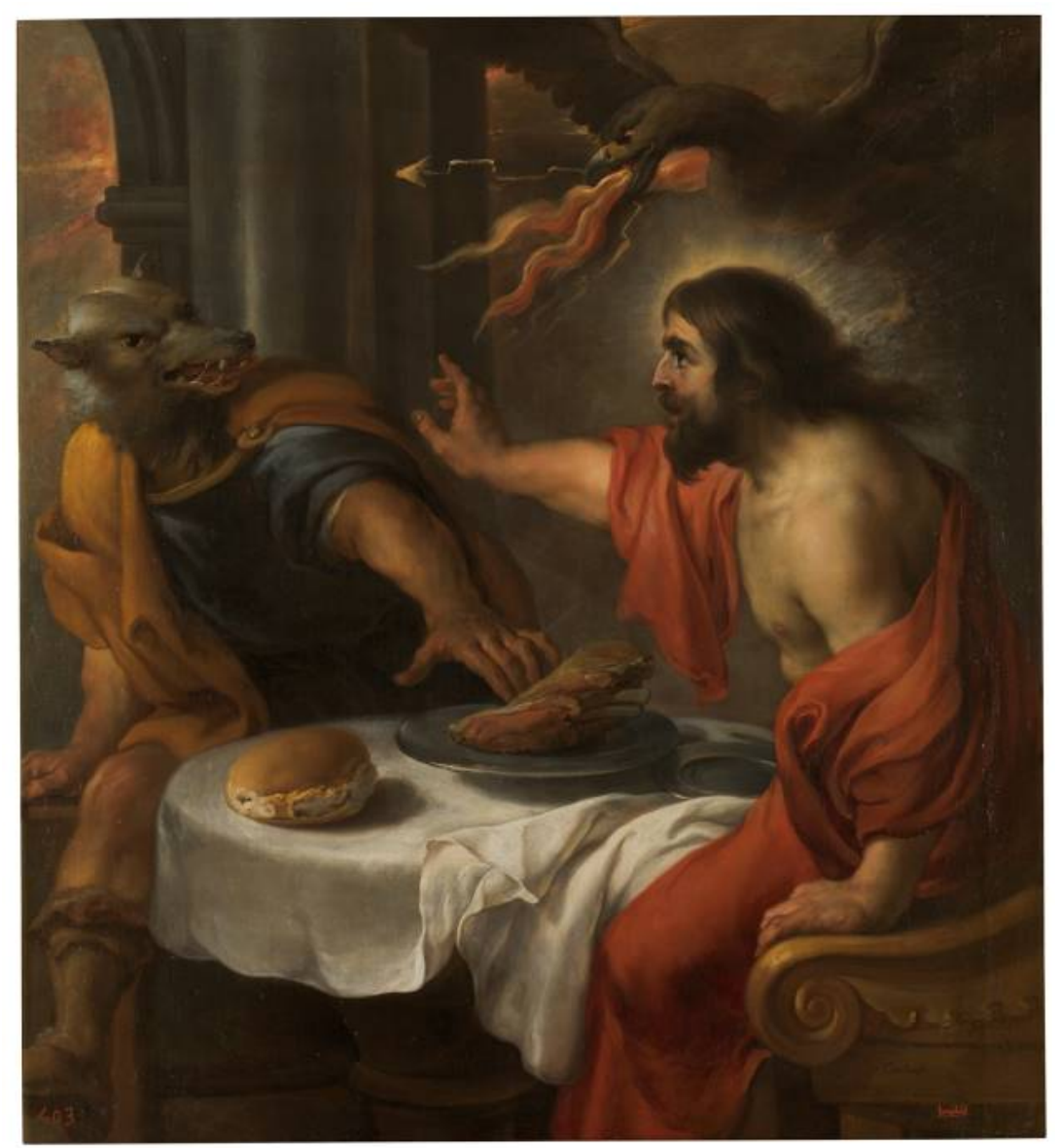

Figura 11: Júpiter y Licaón de Jan Cossiers, 1636-1638. Fuente: (C) Museo Nacional del Prado.

Otro posible ejemplo de una transmutación iconográfica es la del Apolo Sauróctono (fig. 12) ${ }^{73}$ en San Sebastián. Apolo, aparece apoyado sobre un tronco, por el cual asciende una especie de lagarto pequeño. En la mano que no apoya junto al tronco debería sostener una flecha con la cual estaría hiriendo o jugueteando con el reptil y una marcada curva en el movimiento de la escultura, la famosa "curva praxiteliana”. La belleza ideal del desnudo masculino, típica de la escultura de cánones clásicos de los siglos V y IV se reflejó siglos después en los modelos iconográficos de San Sebastián, como nuevo Apolo ${ }^{74}$. Un ejemplo de este podemos encontrar en la iglesia parroquial de Picena (Granada) fechable a principios del siglo XVII y cercana a la obra de Bernabé de Gaviria. La obra se

73 Una buena obra de Apolo Sauróctono, es la copia romana del siglo I-II a. C. del original de Praxíteles del siglo IV a. C., Museo del Louvre.

74 El propio nombre de Sebastián (Sebastianus) quiere decir el honrado o venerado. José Antonio Peinado Guzmán e Isaac Palomino Ruiz, "San Sebastián en el naturalismo escultórico granadino. Estética y símbolo de una iconografía martirial”, Erebea: Revista de Humanidades y Ciencias Sociales 7 (2017): 263. 
encuentra algo trasformada tras repolicromías posteriores, pero a pesar de ello conserva un bello contraposto y una interesante anatomía que la relacionan con los modelos clásicos anteriormente comentados ${ }^{75}$. Otro San Sebastián, estudiado por Romero Torres, es el que realizó Pedro de Mena para la sillería de la catedral de Málaga (fig. 13) ${ }^{76}$.
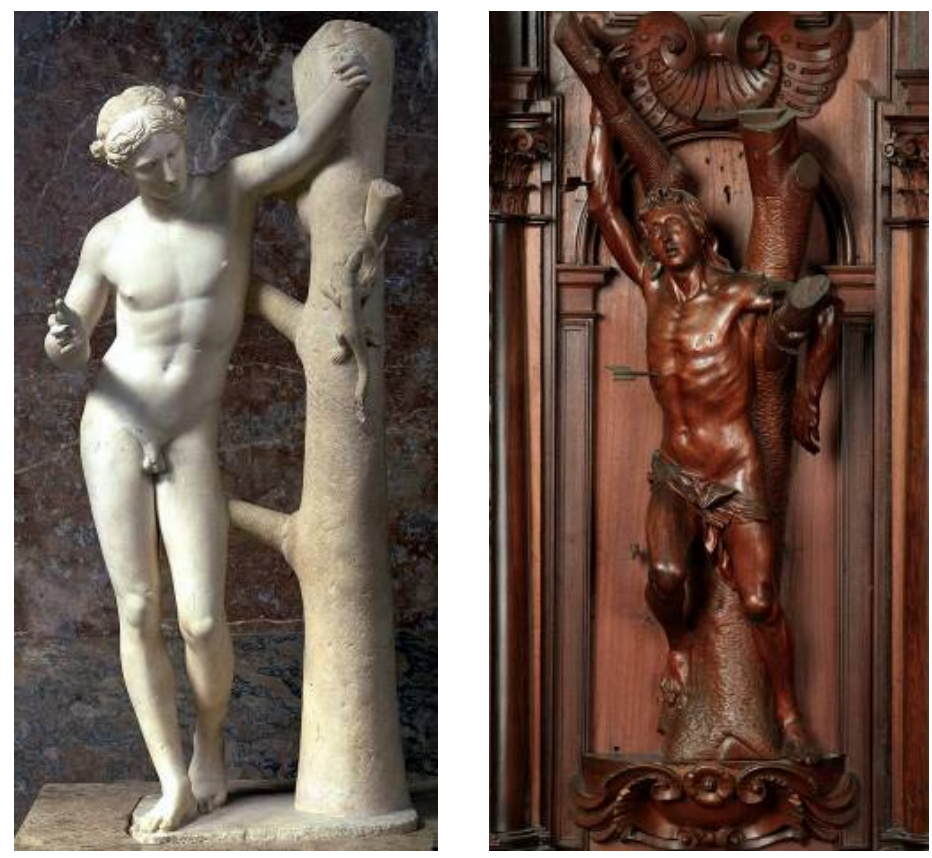

Figuras 12 y 13. Apolo Sauróctono, Praxíteles. San Sebastián, Pedro de Mena, sillería de la catedral de Málaga. Fuente: (C) José Luis Romero Torres.

Como observó Francis Haskell hablando del Laocoonte, el rostro dolorido de este "fue un modelo para una amplia producción de imágenes sufrientes o santos martirizados”. En esta imagen vemos, por ejemplo, que no solo el rostro se gira hacia lo alto, sino incluso también las formas dinámicas que presenta, y como lleva el brazo derecho hacia arriba sujetando un tronco, se asemejan a como luchaba Laooconte con la serpiente. Por último, otra aportación de las influencias de la tradición clásica al arte cristiano en general podría ser las esculturas de Afrodita Cnidia para las representaciones de Eva.

\section{Conclusiones}

Queda en estas páginas mostrada la conversión de tipos iconográficos paganos en cristianos, y como, especialmente al principio, fue necesario el préstamo de tipos clásicos y su reconversión en los nuevos tipos iconográficos demandados por la

75 Peinado Guzmán, Palomino Ruiz, “San Sebastián en el naturalismo escultórico...”, 266.

76 Romero Torres, "Pedro de Mena, el coro de la catedral de Málaga...”, 94. 
Iglesia. Algunas esculturas clásicas (especialmente griegas o helenísticas) que tuvieron mucha repercusión mediante copias romanas han influido en las creaciones artísticas de carácter religioso a partir del Renacimiento, gracias entre otras cosas a la creación de la imprenta. Si hasta el Medioevo, el tráfico de modelos quedaba restringido al comercio de obras de arte, con la introducción de la imprenta se va a dinamizar la praxis artística y, como explica Manuel García Luque, esta aparición de libros y estampas "abriría un universo de soluciones formales e iconográficas" 77 .

Las estampas, fácilmente transportables, corrieron por toda Europa, e incluso a los nuevos territorios descubiertos, con gran facilidad y rapidez. Quizás también en esta difusión de nuevos tipos iconográficos tendrá algo que ver nuevas corrientes de piedad religiosa como la Devotio Moderna con advocaciones o representaciones más cercanas al fiel, como la infancia de Jesús o imágenes pasionales que remuevan al espectador y, por supuesto, imágenes marianas y de los santos como modelos a seguir en la vida espiritual. Así, por tanto, se entienden estos nuevos temas como el Niño Jesús dormido sobre la cruz o el Niño de la espina con un gran valor simbólico, o incluso la nueva concepción del crucificado mucho más cercano a los modelos clásicos y, por qué no decirlo, "más bello".

Pero con todo esto no podemos descartar que algunos de los parecidos formales que hay entre las esculturas clásicas y las posteriores creaciones plásticas religiosas sean simplemente fruto del azar, debido sobre todo a la poca circulación de los artistas de la España Moderna y al restringido conocimiento directo de dichas esculturas.

\section{Fuentes y referencias bibliográficas}

Blanco Frejeiro, Antonio. Arte Griego. Madrid: CSIC, 1996.

Camps Cazorla, Emilio. Inventario del Museo Lázaro Galdiano. Madrid: 1948-1950.

Camón Aznar, José. Guía Abreviada del Museo Lázaro Galdiano. Madrid: 1951.

Coppel Aréizaga, Rosario. Catálogo de la Escultura de Época Moderna Siglos XVI-XVIII. Madrid: Museo Nacional del Prado, 1998.

Ceán Bermúdez, Juan Agustín. Diálogo sobre el arte de la pintura. Sevilla: Manuel de Aragón y Compañía, 1819.

Cruz Cabrera, José Policarpo. "Grabado, dibujo, escultura y pintura. Intercambios y trasvases visuales en la plástica barroca granadina”. En Arte y cultura en la Granada renacentista y barroca: relaciones e influencias. Granada: Universidad de Granada, 2014.

Escuredo Barrado, Elena. “A propósito de la influencia de los grabados como fuente de la escultura barroca sevillana: las estampas de los Wierix”. Archivo Hispalense 300-302, no. 99 (2016): 343-366.

Falomir Faus, Miguel y Marías Franco, Fernando. "El primer viaje a Italia del Marqués del Zenete". Anuario del Departamento de Historia y Teoría del Arte (UAM) 6 (1994):101108.

77 Manuel García Luque, “Fuentes grabadas y modelos europeos en la escultura andaluza (1600- 1650)”, en $\mathrm{La}$ consolidación del Barroco en la escultura andaluza e hispanoamericana (Granada: Universidad de Granada, 2013), 184. 
Gimilio Sanz, David. "Poder, humanismo y religiosidad en tiempos del patriarca Juan de Ribera en Valencia: su colección de escultura clásica”. En ESPACIO, TIEMPO Y FORMA Serie VII. Historia del Arte (n. época) 2 13. (2014): 14-39.

García Cueto, David. "Don Diego de Aragón, IV Duque de Terranova, y el envío de esculturas para Felipe IV durante su embajada en Roma (1654-1657)”. Archivo español de arte 75 (2005): 317-322.

García Luque, Manuel. "Fuentes grabadas y modelos europeos en la escultura andaluza (1600- 1650)". En La consolidación del Barroco en la escultura andaluza e hispanoamericana, 179-256. Granada: Universidad de Granada, 2013.

Gómez Piñol, Emilio. "Las atribuciones en el estudio de la escultura: nuevas propuestas y reflexiones sobre obras de la escuela sevillana de los siglos XVI y XVII”. En Nuevas perspectivas críticas sobre historia de la escultura sevillana. Sevilla, Junta de Andalucía: 2007.

Gómez Piñol, Emilio. “El niño Jesús de la sacramental del sagrario hispalense: introducción al estudio de la génesis de un prototipo distintivo de la escultura sevillana”. En Actas del Coloquio Internacional El Niño Jesús y la infancia en las artes plásticas, siglos XV al XVII. IV Centenario del Niño Jesús del Sagrario, 1606-2006. Sevilla: Pontificia Archicofradía del Santísimo Sacramento del Sagrario de la Catedral de Sevilla, 2010.

González García, Juan Luis y Riaza de Los Mozos, Mónica. "Del saber de la Academia al gusto del amateur: las colecciones de pintura y escultura clásica de Felipe V”. En El arte en la corte de Felipe V. Fundación Caja de Madrid: 2002, 173-194.

Haskell, Francis y Nicholas Penny. El Gusto y el arte de la antigüedad: el atractivo de la escultura clásica: 1500-1900, traducido por José Antonio Suárez Hernández. Madrid: Alianza, 1990.

Jaquero Esparcia, Alejandro. La herencia clásica en las primigenias imágenes cristianas: Apolo como canon de Cristo y San Miguel. Trabajo de Fin de Grado, Facultad de Humanidades de Albacete, 2013.

Lázaro, José. La Colección Lázaro de Madrid. Madrid: La España Moderna. 1926.

Lleó Cañal, Vicente. Nueva Roma: mitología y humanismo en el renacimiento sevillano. 1979. Reimpresión, Sevilla: CEEH, 2012.

Martínez Peláez, Agustín. "Cementerios, tumbas y el espacio sagrado de la muerte” en Actas de jornadas Forma y función en espacios sagrados, coordinador por Porres Benavides Jesús, 5-13. Madrid: Universidad rey Juan Carlos, 2019.

Mora, Gloria y Beatrice Cacciotti. "Coleccionismo de antigüedades y recepción del clasicismo. Relaciones entre Italia y España en el siglo XVIII”. Hispania 56, no. 192 (2019): 63-75.

Morán Turina, José Miguel y Fernando Checa Cremades. El coleccionismo en España: de la cámara de maravillas a la galería de pinturas. Madrid, Cátedra: 1985.

Núñez Fuster, Joaquín Introducción al estudio del origen, formación y desarrollo de las representaciones angélicas infantiles en el arte del renacimiento italiano y de los países transalpinos. Trabajo realizado para la suficiencia investigadora. DEA. Sevilla: 2005.

Oria Segura, Mercedes. "Jugando a ser dioses: Heracliscos y otros dioses niños en la estatuaria hispana”. BSAA 63 (1997): 115-137.

Peña Martín, Ángel "La circulación de modelos escultóricos en el territorio de la monarquía hispánica: el niño Jesús dormido sobre la cruz y calavera del taller de Martínez Montañés”. En 'Copia e Invención’ Modelos, Réplicas, Series y Citas en la Escultura Europea, coordinado por Ana Gil Carazo. Valladolid: Museo Nacional de Escultura, D.L., 2013.

Peinado Guzmán, José Antonio y Palomino Ruiz, Isaac. "San Sebastián en el naturalismo escultórico granadino. estética y símbolo de una iconografía martirial”. Erebea: Revista de Humanidades y Ciencias Sociales 7 (2017): 253-274. 
Pérez Suescun, Fernando. Catálogo de la exposición arte y mito, los dioses en el Prado. Madrid: Museo del Prado, 2018.

Porres Benavides, Jesús. "Una Virgen de la Preghiera en el Museo Cerralbo: el modelo de Carlo Maratta y el impacto de las fuentes grabadas en la difusión de los cuadros devocionales en el ámbito hispano”. Estuco. Revista de estudios y comunicaciones del Museo Cerralbo 3 (2018): 216-229.

Porres Benavides, Jesús. Juan Bautista Vázquez El Viejo, un artista castellano en Sevilla. Sevilla, Editorial Universidad de Sevilla: 2019.

Porres Benavides, Jesús (en prensa). "Obras escultóricas andaluzas en el Museo Lázaro Galdiano”. En actas del IV Congreso Internacional. Coleccionismo, mecenazgo y mercado artístico: Orbis Terrarum.

Ramos Sosa, Rafael. "De Malinas a Lima, un largo viaje para un niño perdido. Notas sobre el niño Jesús montañesino a propósito de nuevas obras en el Perú”. En Actas del Coloquio Internacional El Niño Jesús y la infancia en las artes plásticas, siglos XV al XVII. IV Centenario del Niño Jesús del Sagrario, 1606-2006. Sevilla: Pontificia Archicofradía del Santísimo Sacramento del Sagrario de la Catedral de Sevilla, 2010.

Rodríguez de Ceballos, Alfonso. "Velázquez y la escultura clásica: el segundo viaje a Italia”. En Velázquez: esculturas para el Alcázar, 31-52. Madrid; Real Academia de Bellas Artes de San Fernando, 2007.

Requena Bravo de Laguna, José Luis. “Algunas consideraciones iconográficas sobre la prefiguración de la Pasión de Cristo en su Santa Infancia en la pintura barroca andaluza”. En “Aquenda et allende”: Obras singulares de la Navidad en la Granada moderna (Siglos XV-XVIII), 63-85. Granada: Diputación de Granada, 2014.

Salcedo Garcés, Fabiola. "Las colecciones de escultura clásica en la Roma de Velázquez”. En Velázquez: esculturas para el Alcázar, 53-82. Madrid: Real Academia de Bellas Artes de San Fernando, 2007.

Valdivieso, Enrique. "Una Virgen niña hilando y un Niño de la Espina de Juan Simón Gutiérrez”. Laboratorio de arte 15 (2002): 395-398. 